\title{
TEACING TENSES IN WRITING A SCIENTIFIC PAPER THROUGH PEER TEACHING METHOD FOR FINAL YEAR UNIVERSITY STUDENTS IN COVID-19 ERA
}

\author{
Yana $^{1}$, Mu'man $^{2}$, Yogi Iskandar ${ }^{3}$ \\ 1,2,3 IKIP Siliwangi \\ 11 yanaenglish.edu@gmail.com, ${ }^{2}$ mumanresearch@gmail.com, ${ }^{3}$ ogyramos027@gmail.com
}

\begin{abstract}
The ability to write a research article is one of students' obligation that must be mastered because final year university students are always faced to the final project especially writing an article to be published in national journal as one of the requirement to pass or graduate from the campus where she/he lectures. This research aims to identify the errors of using tenses in students' articles. This research used the method of qualitative descriptive with test - pre-test and post-test as an instrument. Pre-test was done to measure how students understand the tenses with the functions while post-test was done after the result of pre-test needed to continue to the treatment in order to have a high good writing quality. After treatment was conducted, two groups still left three errors consisting of 33 from group 1 and 44 from group 3, and three groups left two errors consisting of 46 from group 2, 29 from group 4, and 15 from group five. From the result of post-test can be decided that peer teaching method is very effective to overcome students' problem especially in understanding or mastering the use of tense in a research article.
\end{abstract}

Keywords: Peer Teaching, Tenses, Scientific Paper

\section{INTRODUCTION}

There are some steps which must be done by university students, and one of them is writing a research paper - a research article. Having a big status being a final year university students indeed feels so tiring because students are faced many assignments that have to be finished. As it has been mentioned before one of them is about writing an article. It is different whether students must write an article and a research paper (skripsi). Besides, writing a research paper need more time to finish it while a research article if it is seen from the time looks it does not take time too much, but it does not mean writing an article is easier than writing a research paper. Both of them includes scientific papers which have to discuss a certain topic or field based on literature review written by masters, field studies, or the result of development (experiment) (Mansur, 2009: 4).

Practically, university students still have a problem writing a research article. They feel confused how to start, and more over how to choose correct tenses in presenting the event or time. It becomes a burden because English has different language forms instead of other languages. The writer has to know when he/she uses present, past, future, or past future tense. The use of correct tenses will present the right meaning, but if students write incorrect tenses, it will become big problems for him/her that comes from readers or other researcher because the writers must be responsible for what they have written.

This problem does mean it cannot be overcome. The fact is choosing the best method will help students to understand tenses easily, so the point is how the teacher can innovate in order to be 
able to make students understand and write an article well with using correct tenses. By this way, students will have a good spirit and high motivation to finish his/her final study without any hard obstacle.

One of the best methods which can be applied to the students is peer teaching. It is about someone or several persons of students who are pointed to help the teacher to master learning material, and he/she can give a guidance to the classmates. With this method, it is usually more effective as students will be more active and they do not have to feel shy when asking something related to the material (Bound, et al, 2001).

It must be guaranteed this method can become alternative for students who do not have a bravery to ask the teacher directly and for those who experience a difficulty in the process of learning. It is hoped that it can make an easy understanding because students can be more active without any doubt or any shy feeling. In the process of applying this method, teachers or lecturers just listen to the students who is explaining the material. Teachers or lecturers may give addition when student finish explaining or they control student so that there are no mistakes when explain the material.

Bound (2001) said that the highest effective learning model to be allied in the process teaching and learning is peer teaching. It is also called as per learning. This method can be mentioned as the most effective one because students can share their idea, thought, and understanding one another without feeling doubt or nerves. Students can support each other in order to deliver an understanding. Then, it is so useful way to make students better in developing their skill especially in English language.

Beside, Silberman (2006) cited from Iva (2009) explains that peer teaching is a learning approach which point one student who is be able to teach to other students. This application is supported by Suherman (2003:277). He said the language utterance of friends is more understandable as students do not have a doubt feeling, humble, shy, and so forth, so students who have lacked of understanding are supposed to have a bravery to express what makes them difficult and they will feel enjoyable stating his/her problem.

Next, Jarvis (2001) said peer teaching is a learning activity where it is focused on students' center. It means that students control the classroom activities - process teaching and learning. It is also called as "a learner-centered activity". Now days, it is often found several institutions that have been applied this method because it gives a chance to all students to develop what they have understood. It is hoped that it can give a beneficial thing either for institutions or for students. Moreover for university students they are obliged to be able to understand every learning material and it must be discussed in the classroom.

Trying to see what is always seen from university students is the purpose of this research because it still becomes a main problem from those who want to finish the study. It can been from the fact on the field that students must build their confidents and increase their knowledge so that they can overcome this problem. For example, they read a lot, ask a lot, or discuss a lot. Then the most important thing they have to do is students must often discuss with the classmates about their difficulty.

From the three things mentioned above, peer teaching is something that cannot be put behind. It is one alternative to develop students understanding in mastering learning material. Reading, asking, and discussing may be habitually done either in the classroom or out of the classroom, but peer teaching must be more serious to be conducted in order to get a significant result 
especially in this era which called as covid-19 era. This method can be applied easily. Students can use any devise such as zoom meeting, Google meet, office 365, WhatsApp Video call, and so many more.

This application can help either teachers or students to apply this method and it is more possible to be done in Pandemic era. Students cannot feel afraid of infecting this virus because learning is done through a long distance. Hence, the researcher sees this is a problem which can be overcome or way that can be done to develop students' skill. Through this research title "Increasing Tenses Knowledge Skill in Writing A Scientific Paper trough Learning Model of Peer Teaching for Final Year University Students In Covid-19 Era, it is hoped that this method can solved students' problem or difficulties in comprehending tenses material in writing a research article.

\section{Literature Review}

\section{A. A Research Article}

A research article is a scientific paper which is admitted either in national or international publication. All people who are correlation to formal education cannot be apart from writing a scientific article. Indeed, they have a different need. It is special in higher education (university), one of the three things that have to be fulfilled by a lecturer is writing a research article. It is needed to his/her career and the university where he/she teaches while university students must write a research article whether it is published in national or international journal. It has to be done by every student as a requirement to graduate. As the following statement below:

The incorporation of scientific research articles as an essential part of the curriculum for undergraduate science students is becoming more prevalent, since more and more faculty members are finding out the value of exposing students to primary literature as part of their course-work (e.g. (Hoskins, Lopatto, \& Stevens, 2011; Hoskins, Stevens, \& Nehm, 2007; Kozeracki, Carey, Colicelli, \& Levis-fitzgerald, 2006; Quitadamo \& Kurtz, 2007) in Yeong, F. M. (2014).

It can be understood that writing a research article has become a part of university curriculum or syllabus because it is not only to train students to go national or international, yet this is also to grind an academic students' skill in writing in order to have a biggest experience or high confident after they graduate then.

\section{B. Tenses}

Tenses or it something that is used to be called as the form of time in English. It is a pattern which give a big meaning effect because English has different word forms called as present, past, and future or in Indonesia is called as verb 1, verb 2, and verb 3. Then, present participle also brings meaning concept to the event. In general, there are 16 tenses that must be understood by second or foreign learners. From those 16 tenses, it is agglomerated into four - present, past, future, and past future (Supono, C. 2004). However, in writing a research article, three tenses are supposed to be used namely present, past, and future.

\section{Present}

This tense in general expresses an event which shows a daily activity, a fact, or general truth such as students' daily activity in every day, sun or world rotation, place location. In a research article, this tense is usually put in writing an introduction where it shows fact or event in relation to a research. Besides, it is also used to discuss the data gained from the research subject that has been analyzed. It is chosen because in the discussion the researcher must compare what have been got with other research result. It is also matched with the theory used. 
2. Past

This tense is usually expresses what have been done, or it talks about past. This can also express about a habitual action in the past. This tense must be allied when writing or showing the result in the finding. Without any time signal, this tense form can deliver the true meaning to the readers. Besides, it is also used to describe the method used in the research.

3. Future

In general, this tense is used to express a research planning, or it is usually applied when the research is still in the form of proposal. The fact is it is not only used only in a proposal, but it is also used in the introduction where the researcher explains for example the planning of applying method which has a good impact to the learners.

\section{Learning Method}

Method can be called as the most important thing in the process teaching and learning. It must be determined well to make students easy to comprehend the knowledge. Sutikno (2014:33-34) states that method means a way literally. It is called as a way or procedure used to achieve a certain purpose. The word of "learning" is mentioned as an effort done by teachers to create self-awareness in students' spirit. Hence, it could be explained as learning method is the way to proceed learning material done by educators in order to achieve its purpose.

In line with above statement, Hamzah and Burdin (2011: 7) defines learning method is a way used by teachers to achieve the learning objectives. They mention the learning method which is appropriate with students' need will help teachers and students to comprehend the goals. Komalasari (2010: 56) clarifies that learning method is an implementation of how teacher can deliver knowledge to the students specifically.

\section{Peer Teaching}

The general definition of peer teaching is a method which is applied by a students to teacher his/her classmates so that others students can understand the learning material (Majid, 2013). This method is applied by a person who teaches the same age or the same class, and it gives an opportunity to the students to learn something in a very good mastery. In another word, student become a teacher for other students (Jalil, 2014).

Another statement mentions that peer teaching a student helps other students with the same class or same level with him/her (Susilowati, 2009) while (Sawali, 2007) in Hafizah says peer teaching is an appointment purposed to one or several students to become a teacher for his/her classmates who face a difficulty in understanding learning material. This choice is usually pointed to the students who have more capability instead of other students. There are five steps which have to done in applying peer teaching (Huda, 2013):

1. Orientation

In this step, teacher or lecturer determines learning material, previous learning, and learning procedure. It is supposed to be done in order to be appropriate with what has to be got by students.

2. Presentation

This step encourages teacher or lecturer to explain the concept what has to be done by students especially for those who want to be pointed as teacher to change his/her position.

3. Well-managed practice 
This step asks the teacher or lecturer to lead every group of students to make them understand some rules including responses or questions from students that must be answer clearly.

4. Teacher's control

In this step, teacher or lecturer asks the students to practice peer teaching with his/her guidance. Here, teacher must watch what they are explaining or doing so that there are no mistakes when a representative teacher is explaining the material.

5. Independent practice

In this step, a representative teacher control all class activities. Teacher or lecturer just see from behind the class room. Then, teacher is just allowed to give a feedback when the process of practice has been done.

\section{METHOD}

This research used a descriptive qualitative where the researcher presented the result of this research in the form of descriptive, even it was used pre-test and post-test because the tests was used just to measure whether there was a positive change from the students after they were given treatment through peer teaching method. Cresswell (2010: 8) mentions that qualitative research is a research process which gives an understanding to person's habit in daily interaction especially in social life and problem faced by human. This was so appropriate with the problems found in university students where they found difficulty when writing a research article to fulfill the last second last requirement obliged by the institution.

This research was conducted in one of the institutions in Cimahi where the subjects of this research were taken from the last year university students consisting of eight respondents. Those research steps included making a learning module to be prepared. Then, the data were gained from pre-test and post-test. Before students were given a treatment, they were asked to write a research article. Then, after they wrote it, the researcher read students' writing in detail to see whether they made mistakes in using tenses or not. After the researcher knew students' errors, the researcher applied peer teaching method to give students a treatment. Then, the researcher saw students article after they were given a treatment.

In writing the article, the researcher asked the students to be divided into five groups, so that they can help each other when facing some difficulties. The fact showed that three students wrote the article personally, two students cooperated to write an article, and three students made only one article, it was totally collected five articles. Then, the instrument of this research was the researcher himself.

\section{RESULTS AND DISCUSSION}

\section{Results}

In this part, the researcher shows the result from data analysis. It is the same as what has been explained above that the data were taken from eight university students and they were divided into five groups, so there are five articles here which showed the result of the effectiveness for applying peer teaching in giving understanding to students about using tenses for writing a scientific article. Here is the following column modified from (Prasetiya, 2017).

Table 1. The Error Result of Students' Test

\begin{tabular}{lll}
\hline \multirow{2}{*}{ Group $\quad$ Student ID } & \multicolumn{2}{c}{ Errors } \\
\cline { 2 - 3 } & Pre-test & Post-test \\
\hline
\end{tabular}




\begin{tabular}{llll}
\hline \multirow{2}{*}{1} & 18220205 & 33 & 3 \\
\cline { 2 - 3 } & 18220231 & 46 & 2 \\
\hline 2 & 18220155 & 44 & 3 \\
\hline 3 & 18220380 & 29 & 2 \\
\hline 4 & 18220380 & 15 & 2 \\
\cline { 2 - 2 } 5 & 18220010 & 18220203 & \\
\cline { 2 - 3 } & 18220128 & & 2 \\
\hline
\end{tabular}

From the data above, it is seen that before students were given a treatment, they were asked to make a research article. The data showed that students made mistakes when using tenses. It was so significant because the use of wrong tenses will deliver misunderstanding meaning, but after students were given a treatment, the errors looked less and it seemed very effective to apply peer teaching in overcoming this problem for students.

\section{Discussion}

The data above showed the result of data analysis gained from final university students' articles. It can be seen from the data above that there were two kinds of activity done by the researcher - pre-test and post-test to measure how students mastered in understanding tenses used for writing a scientific article. Besides, as what has usually been doing by a researcher, before going to the post-test, students will be given a treatment in order to understand the material well. Here it was also done by the researcher. He gave a treatment to the final university students especially to the student who was given an opportunity to become a substitute teacher for her classmates.

\section{Pre-test}

This step asked the students to make a research article as what they understand how to use correct tenses - in abstract, introduction, method, result, discussion, and also conclusion. It was seen from students' background of scientific. They would not face many difficulties as their major is English education study program which had enough knowledge in understanding the use of tenses. With the result that this research was not broken the rule by taking right participants.

Apparently, even they are majoring English education, they still made mistakes in choosing the correct tenses. It was seen from the result all groups showed many errors either from the smallest 15 to the highest 46. From this data, the researcher decided to give a treatment to the students in order to minimize errors made in writing a scientific article because it has a general term moreover this article will be publish on national or international journal article. It will bring effects not only to the writer but also to the institution where students are taking collage.

\section{Treatment}

After the researcher saw the result of pre-test, the researcher took an action to give a treatment to the students. It was give so they would understand the use of tenses for writing an article. One of them was chosen to be a substitute teacher to apply peer teaching. Then, it can be seen from the result of post-test. The errors looked very less. It means that the treatment, peer teaching method, appeared so effective.

\section{Post-test}

Post-test was done to measure how effective peer teaching method applied to the students. With the same article made by students even personally or group, they were asked to correct wrong tenses in his/her article. Looking at the result of the post-test, students had a good understanding. It proved that all students could solved the problem and showed a good result. 
From the first time before students ware given a treatment, they made many mistakes, but after the treatment was done, they finally made it to write a good research article.

It is seen from group 1. From 33 errors, students can minimize errors become two so can group 3 , he/she also still leaves two errors. It is also amazing for group 2, 4, and 5. There are two errors left from 46 from group 2, 29 from group 4, and 15 from group 5. This result shows that there is a significant development of students' understanding for the use of tenses for writing a scientific article.

\section{CONCLUSION}

Writing is one of the best activities which must be done not only by academicians, but also for general because writing can be called as an expression to state feeling or to dispense a hobby for a part of people. For academicians, writing is a must as they are demanded to produce a work even as a student or as a teacher/lecturer. Students have to write something in relation to the lecture - assignment given buy a lecturer, while for lecturer it is to be done because he/she must be run three obligation (duty) - teaching, researching, and dedication to societies.

There are several kinds of writing - journal, article, proposal, paper, and so on. Those often become a problem especially for students who are in final semester. There are occupied with lots of homework or assignments. The challenge comes it is not only hard to kick off writing, but the lesson which has been learnt in the previous semesters is not mastered yet especially for a research article because students must publish in minimally reputed national journal.

By having peer teaching method, it will facilitate students who have a problem with material understanding because this method does not involve a direct lecture, but it involves one of students who change a lecturer to teach or deliver the material. This method is very appropriate for those who do not have a bravery to discuss or ask to the lecturer directly. This method proves effective as it has been applied in this research, and the students' understanding of material tenses - looks significant.

\section{ACKNOWLEDGMENTS}

Place Acknowledgments, including information on the source of any financial support received for the work being published. Place Acknowledgments, including information on the source of any financial support received for the work being published.

\section{REFERENCES}

Aisyiah, K., Sutikno, S., \& Latra, I. N. (2014). Pemodelan Konsentrasi Partikel Debu (PM10) pada Pencemaran Udara di Kota Surabaya dengan Metode Geographically-Temporally Weighted Regression. Jurnal Sains dan Seni ITS, 3(2), D152-D157.

Bruffee, K. A. (1995). Peer tutoring and the "conversation of mankind.". Landmark essays: Writing centers, 9, 87-98.

Creswell, J. W., \& Poth, C. N. (2016). Qualitative inquiry and research design: Choosing among five approaches. Sage publications.

Hadiono, A. (2017). Analisis Faktor Penghambat Penyelesaian Skripsi Mahasiswa STIA Banten. Jurnal Niagara, 1(1), 168-177.

Hafizah, E., Halidjah, S., \& Nursyamsiar, T. (2015). Pengaruh Metode Tutor Sebaya Terhadap Hasil Belajar Di Kelas V Sekolah Dasar Kota Pontianak. Jurnal Pendidikan dan Pembelajaran Khatulistiwa, 2(2). 
Hoskins, S. G., Lopatto, D., \& Stevens, L. M. (2011). The CREATE approach to primary literature shifts undergraduates' self-assessed ability to read and analyze journal articles, attitudes about science, and epistemological beliefs. CBE_Life Sciences Education, 10(4), 368-378.

Hoskins, S. G., Stevens, L. M., \& Nehm, R. H. (2007). Selective use of the primary literature transforms the classroom into a virtual laboratory. Genetics, 176(3), 1381-1389.

Huda, M., Maseleno, A., Shahrill, M., Jasmi, K. A., Mustari, I., \& Basiron, B. (2017). Exploring adaptive teaching competencies in big data era. International Journal of Emerging Technologies in Learning (iJET), 12(03), 68-83.

Jarvis, M. (2005). The psychology of effective learning and teaching. Nelson Thornes.

Junaidi, A. W., Saptani, E., \& Suherman, A. Penggunaan Model Peer Teaching Terhadap Keterampilan Pencak Silat Seni. SpoRTIVE, 1(1), 51-60.

Kozeracki, C. A., Carey, M. F., Colicelli, J., \& Levis-Fitzgerald, M. (2006). An intensive primary-literature-based teaching program directly benefits undergraduate science majors and facilitates their transition to doctoral programs. CBE-Life Sciences Education, 5(4), 340-347.

Lestari, W., Susilowati, E., Saputro, A. N. C., \& Mahardiani, L. (2013). Pembelajaran Kimia Melalui Pendekatan Contextual Teaching and Learning (Ctl) Dengan Metode Praktikum Yang Dilengkapi Dengan Lembar Kerja Siswa (Lks) Dan Diagram Vee Ditinjau Dari Sikap Ilmiah Siswa Pada Materi Pokok Perubahan Materi Kelas VII Semester G. Jurnal Pendidikan Kimia, 1(1).

Majid, A., \& Mansur, S. A. (2010). Metode Penelitian Pendekatan Kuantitatif dan Kualitatif: R\&D. Bandung: Alfabeta.

Mansur, M. (2009). Profesionalisme Guru Pendidikan Agama Islam SMA Negeri 1 Tapin Selatan Rantau.

Munawaroh, A., \& Christijanti, W. (2013). Penerapan Model Pembelajaran Berbasis Proyek untuk Meningkatkan Hasil Belajar Sistem Pencernaan SMP. Journal of Biology Education, 2(1).

Prasetiya, M. . (2017). Penerapan Metode Pembelajaran Peer Teaching untuk Meningkatkan Hasil Belajar Siswa X Pada Mata Pelajaran Dasar Pemrograman di SMK Negeri 2 Salatiga.

Quitadamo, I. J., \& Kurtz, M. J. (2007). Learning to improve: using writing to increase critical thinking performance in general education biology. CBE—Life Sciences Education, 6(2), $140-154$.

Sabri, T. (2017). Practical Ways Internalization Tematik by Students in Learning through Peer Teaching in PGSD FKIP at Tanjungpura University. Journal of Education, Teaching and Learning, 2(1), 79-83.

Silberman, M. L. (2006). Training the active training way: 8 strategies to spark learning and change (Vol. 12). John Wiley \& Sons.

Sulistyani, Iva. (2009). Penerapan Model Pembelajaran Matematika dengan Pendekatan PeerTeaching Ditinjau Dari Minat Belajar Siswa di SMP Negeri 2 Trucuk (Doctoral dissertation, Universitas Muhammadiyah Surakarta).

Uno, N. R. (2015). Validasi Metode Analisis Untuk Penetapan Kadar Tablet Asam Mefenamat Secara Spektrofotometri Ultraviolet. PHARMACON, 4(4).

Yeong, F. M. (2014). How to read and critique a scientific research article: Notes to guide students reading primary literature (with teaching tips for faculty members). World Scientific Publishing Company. 
